\title{
Competitive strategy based on transformation and dynamic capabilities in resulting business performance of Islamic microfinance institutions
}

\author{
Harry Sutanto ${ }^{1 *}$ \\ ${ }^{1}$ Consultant, Practitioner and Lecturer of several major universities and corporation in Indonesia \\ *Corresponding author
}

\begin{abstract}
Since there are 100 million people with an income less than USD2.00 per day, poverty is considered as a major problem in Indonesia. Microfinance as an important solution in poverty alleviation program, could not yet meet the needs of 500 million poor people in need of small business credit to improve their business performance.

Islamic microfinance institutions ("MFIs"), especially Baitul Mall wat Tamwil ("BMT"), is considered as major instrument in regulating overall social system includes the existence of human and high values. Although the number of BMT is lower than other Islamic MFIs, but it has higher number of beneficiaries, thus able to serve and fulfill the need of microfinance's business. Along with the increasing role of BMT within microfinance business, it is necessary to execute a dynamic transformation associated with a variety of other factors to improve its business performance.
\end{abstract}

There is not yet any study that explores and evaluates the relationship among transformation, dynamic capability, competitive advantage and performance constructs in Islamic MFIs. Studies on the effect of transformation and dynamic capability approach in improving the BMT's performance, either through competitive advantage or not, will become a positive contribution either for BMT or Islamic MFIs to overcome dynamic changes faced in implementing their mission to alleviate poverty.

The result of hypothetical descriptive test are (a) transformation and dynamic capability approach are able to respond as opportunities to improve the company's quality of management and profit; and (b) the company is able to increase its competitive advantage and business performance. To strengthen the descriptive test results, a statistical test by using Partial Least Square method is required on the hypotheses.
Keywords - transformation, dynamic capabilities, competitive advantage, business performance and Baitul Maal wat Tamwil

\section{INTRODUCTION}

\section{Background}

The number of poor people in Indonesia by March 2016 was 28 million or 11 percent of the total population of Indonesia, divided into 10.34 million in the city and 17.67 million in the rural area. Although there is a decrease of 580.000 people compared to March 2015, the index of the depth and severity of poverty in the country deteriorates, where rural poverty gap index declined from 2.55 per cent in March 2015 to 2.74 per cent as of March 2016; and the poverty suffered index declined from 0.71 percent in March 2015 to 0.79 percent in March 2016 (Poverty Index's Survey, July 18, 2016).

Previously, poverty was always associated with economic factors, measured by an income or individual or community's consumption level. It is based on assumption that the improvement of economic factors will have a positive implication effect to poverty alleviation program, which generally focuses on the economic growth.

But the increase in gross domestic product ("GDP") does not in itself bring the improvement of individual or community's living standard due to the facts that: a) the population growth is greater than the economic growth within developing countries; and b) the existence of social injustice and economic imbalance which causes the growth of output to be distributed unevenly. On the other hand, the poverty problem is not just the number and percentage of poor people, but it also including the level and depth of poverty suffered index. And poverty reduction policies should be able to reduce the number of poor people as well as reducing the level of depth and gradation of poverty (Kompas, July 19, 2016). 
Microfinance has been growing very rapidly, and seen as undergoing a microfinance revolution (Robinson, 2001 and Natawidjaja, 2014), because it is considered effective for and even becomes a critical factor which could not be separated from the poverty alleviation program. But behind the achievements of microfinance, Stern (2011), as presented by Rodman (2011) suggests that according to the international development community, microfinance in its current form with 200 million customers worldwide is not yet able to meet the high expectation of poverty alleviation program. World Bank also stated that microfinance could not meet the needs of about 500 million poor people to small business credit,

Microfinance should be put in a broader perspective, including the diverse interests, proportionally. Therefore, MFI's radical and evolutionary transformation is highly needed, by implementing fundamental changes in the form of system, commercialization, organizational and ownership structure, decentralization in operational systems, and balance between formal and informal financial institution, as well as oversight of management.

Islamic Economics embrace the ideology of economic balance between the rights of individuals and society as schools of economics moderate and do not oppress the people, especially the poor society by implementing a dual approach that is using the principle of profit and nonprofit, mission-based and market-based and not to carry out trade and create wealth. Islamic MFIs as part of the Islamic Economic System, should implement Islamic principles in development activities and abandon the financial business that harm the symbols of Islam.

As with conventional micro-credit organizations, Islamic MFIs understand that its mission is to change the habits and customs of the people. Therefore, as an Islamic organization, Islamic MFI has the responsibility to determine the type of economic change as well as social, moral and spiritual as the basis for implementation. A niche market of Islamic MFIs does not only incorporate but has the potential to become a market model in the microfinance industry and Islamic microfinance.

Although Baitul Maal wat Tamwil ("BMT") or the Center for Independent Business Integrated is smaller than other Islamic MFIs, it has a more beneficiaries so it is more able to touch microfinance business. Also, BMT is offering more innovative and various products than other Islamic MFIs. This is evidenced by the 3,000 BMT spread throughout Indonesia, the assets of more than Rp 1 trillion, 30,000 managers, and serves more than two million savers and lends to more than 1.5 million microentrepreneurs (with many remote locations) with a capital base smaller than the capital needed to establish rural banks which derived from its founder.

Due to the fact that the world and business is moving and growing dynamically, none of the business organization, including BMT, can be static over time. It has to change dynamically in accordance the circumstances that exist, and adaptive to the dynamic developments that occurred. Therefore it is necessary to implement a transformation that is combined with a dynamic capabilities approach to produce a superior business performance, either through competitive advantage or not.

The dynamic capability's approach is a strategic reconfiguration of resources and organizational capability to adapt to the dynamic conditions, supported by the integrative capability in the form of leverage (diffuse), redirect (transfer), merge (combine) and update (renew) the information and knowledge that exist within the entire company (Eisenhardt and Martin, 2000). Basically, the dynamic capability's approach is not a new approach and some has been implemented but are not recognized by the company (Teece, 2009).

Competitive advantage is a means of achieving the ultimate goal of the company in the form of performance that generates high profits, which is supported by a superior resources, a unique and distinctive value creation strategy, a strengthened core values, an excellence and competitive business management; and a high change adaptability. Competitive advantage is suspected as an intervening variable as the aggregation of the implementation of the transformation and dynamic capabilities approach to achieve an optimum business performance.

\section{Problem identification}

\section{Baitul Maal wat Tamwill as a Featured Islamic MFIs}

As an acceleration strategy, BMT architecture is arranged as a guide for further development on the basis of six major programs, namely a) strengthening of national structures; b) improving the quality of regulation; c) increasing supervision; d) improving the quality of management and operations; e) developing infrastructure and f) protecting customer. In addition, according to the Shafi'i Antonia, seven concepts to enhance the BMT's performance is: a) the adequate capital structure (IDR500 million-1 billion); b) a competence human resources with D3 minimal education background, has the spirit of development and experienced; c) minimal IT infrastructure, such as computers and accounting software; d) various business with reliable products; e) an adequate network to reach the market, a mosque, as well as scholars and community leaders; f) a regular basis public coaching; and g) an integrated risk management includes management strategies, operational, credit, market, liquidity, legal, and reputation.

\section{Transformation}

Transformation is the metamorphosis of one form into another, fundamentally, strategically and comprehensively (French et al, 2000) to leverage existing resources, changing the paradigm of the company as a 
whole (Firmanzah 2012). Transformation as a way to be different, include changes in the deepest level of beliefs, values and assumptions, bringing a fundamental change in the behavior of individuals and organizations as well as systems and structures related organizations, has become a necessity in a more dynamic business condition nowadays and future to come (Soetjitro, 2001).

Benchmark for the success of transformation among others, (a) changes in performance through revenue, profit, turnover, etc; and (b) changes in the behavior of human resources towards a better, measured through media observation, survey, or assessment. While the approach used specifically $5 \mathrm{R}$ namely (a) reframing or reconfiguration; (b) restructuring or rearrangement; (c) revitalizing or strengthening back function; (d) renewal or update the views; and e) re-inspiring or planting commitments (Norman, 2001; Charmer, 2009; Scott, 2000) was determined by the presence of: i) a sense of urgency; ii) commitments; iii) a paradigm shift; and iv) high performance standards (Soetjitro, 2001).

\section{Dynamic capability approach}

Dynamic capabilities approach emphasize on the process of adaptation and continuous improvement over the activities of the existing organization so as to respond and adapt to the dynamic changes occurring within or outside the company, to remain in existence and competitive in a turbulent environment (Lawson and Samon, 2001) as well as be able to realize the company's vision (Pearce and Robinson, 2012; Eisenhardt and Martin, 2000; Priem and Butler, 2000; Lawson and Samon, 2001; and Pearce and Robinson, 2012).

In line with a very dynamic business situation, a dynamic capabilities approach as a form of perspective future strategies in the form of a) improving the efficiency, effectiveness, and productivity; b) toughness to maintain viability under conditions of uncertainty and change very quickly; c) the ability to display and maintain a competitive advantage; and d) the courage to change the organizational culture or less in line with the expected changes (Siagian, 2002) became a necessity and should be integrated into the transformation strategy.

\section{Competitive advantage}

Competitive advantage relates to the ability of the company to obtain a sustainable perspective beyond competitors that allows the company to obtain superior performance (Pitts and Lei, 2003:7) as illustrated in the following diagram.

According to Ferdinand (2000) competitive advantage is very important when a company enters a highly competitive market, in which the success (short term and long term) is determined by its ability to surpass competitors in building the foundation of the achievement of excellence. Glueck et al. (1987) in Yuwalliatin (2006) suggests that companies that the characteristics of companies that successfully embody a competitive advantages are a) has a special competence; b) able to create imperfect competition; c) meet the sustainability aspects; d) align with the external environment; and e) obtain higher returns than competitors.

The achievement of competitive advantage becomes a necessity since companies that are able to achieve competitive advantage will also be able to achieve an outstanding holistic (financial and non-financial) business performance.

\section{Business performance}

According to Powell (1992), in explaining the variance in financial performance, strategic researchers and industry economic expert stressed on many industry factors, market share, generic strategies and membership in strategic group. Those perspectives are then integrated in study that examined the impact of connectedness (alignment) organizations against financial performance, related to the influence of the industry, market share and strategy.

Based on the underlying perspective, assessment of corporate performance can be measured through financial perspective (sales, market share and profitability) as well as non-financial perspective (level of satisfaction and success, and decision-making and supply chain perspectives).

\section{Purpose of study}

To propose the result of study and analysis of:

1. An overview of the transformation and dynamic capability approach implemented, the embodiment competitive advantage and the achievement of business performance by BMT;

2. The effect of the transformation of the competitive advantage, either simultaneously or partially, in BMT;

3. The effect of dynamic capability to competitive advantage, either partially or simultaneously, in BMT;

4. The effect of competitive advantage to business performance in BMT; and

5. The direct effect of the transformation and dynamic capabilities to business performance, as well as indirect effect through competitive advantage in BMT.

\section{Further purposes of study}

The study will be benefited to:

1. The development of the science of strategic management to strengthen and develop the existing theories, or even produce a new theory in the 
management of the company, the relationship among transformation, dynamic capabilities, competitive advantage and business performance are integrated tested; where several previous studies have not integrated these constructs in this study.

2. To contribute a useful and meaningful input, for the related BMT, BMT Association and stakeholders widely, especially in facing business conditions change and the potential performance deteriorated. The study of relationship among transformation, dynamic capabilities approach, competitive advantage and business performance, can be used as a foundation in strategic support and achievement of company's sustainability; which could also be implemented on the management of MFI's in general.

\section{METHOD}

\section{Research characteristics}

Characteristics of research based on the methods used are as follow:

1. Based on its objectives, the methods used are

a. descriptive survey to describe systematically and accurately on the object of research i.e. transformation, dynamic capability approach, competitive advantage and business performance with the Balanced Scorecard approach; and

b. Explanation survey to find causal relationships between variables through hypothesis testing to answer questions and research objectives, in order to obtain an explanation and description of the phenomenon developed the model to complete the research.

2. The unit of analysis in this study is the BMT while the unit of observation is the top managers as respondents. The research's time horizon is cross sectional, where the survey carried out at a time (one shoot survey).

3. Questionnaire method is used in the form of filling a series of questions that are compiled in a list to the respondent;

4. The observational studies, in which researchers are working to carry out observations of phenomena that exist without the intervention and manipulation of the observed phenomena. The objectification of researchers needed to obtain valid results of observations on a phenomenon as a form of objective reality; and

5. Economic approach especially the management strategy with the main study of management control systems and management strategies, particularly regarding the uncertainty of the transformation and dynamic capabilities approach, as well as other variables that competitive advantage and business performance as measured by Balanced Scorecard.

\section{Operationalization of variables}

Proposed indicators to measure the research variables, both dependent variables, intervening or independent.

\section{Measurement methods}

The measurement method in this study is divided into two types:

1. The use of mathematical equations to measure the company's performance using the Balanced Scorecard approach; and

2. Five point Likert scale, to obtain a more specific response, given by the respondents in the study. The measurement results are then used to test the effect of each variable.

\section{Data variables grouping}

Basically the data required in the study were classified into:

1. Transformation;

2. Dynamic capability approach;

3. Competitive advantage; and

4. Business performance measured based on the Balance Scorecard method, namely financial perspective, customer, internal business processes and learning and growth.

\section{RESULTS}

The result of hypothetical descriptive test are (a) transformation and dynamic capability approach are able to respond as opportunities to improve the management quality and achieve the company's profit; (b) the company is able to increase its competitive advantage; and (c) the company is able to improve its business performance.

To strengthen the descriptive test results, a statistical test by using Partial Least Square method is required on hypotheses that have been made.

\section{CONCLUDING REMARKS}

Several concerns and reflections of the implementation of the development of the science and suggestions for further research are as follows:

1. The need for the attitude of being humble and believe in expectations, particularly because of the conclusions made by the researchers will not mean much for the poor who still survive and strive in their 
own way. Microfinance Institutions will continue to grow and develop themselves with creativity and capability, whether viewed positively or not. Yet what is to be decided or not decided today will have implications for the development of micro-finance in the medium or long term.

2. To enhance analytical models, researchers can then consider some of the following:

a. Identify any other factors that affect the performance of the business in addition to the transformation and dynamic capabilities so future researchers can examine the variables;

b. Identify any other factors that affect the competitive advantage in addition to the transformation and dynamic capabilities, so future researchers can examinethose variables; and

c. The research model can be implemented also in other kind of business to strengthen its feasibility in researching the phenomena related to the company's business performance improvement strategy.

\section{REFERENCE}

Chen, HH; dan Lee, PY, 2008. The Driving Drivers of Dynamic Competitive Capabilities: A New Perspective on Competition. European Business Review 21.

Chesbrough, H., and Rosenbloom, R.S. 2002. The Role of the Business Model in Capturing Value from Innovation: Evidence from Xerox Corporation's Technology Spin-off Companies. Industrial and Corporate Change, 11(3), 529-555.

Collins, D.J. 1994. Research Note: How Valuable are Organizational Capabilities? Research Notes. Strategic Management Journal, Winter Special Issues, 15, Hal. 143-152

Creswell, J. 2009, translated by Achmad Fawaid, 2014. Qualitative, Quantitative and Mixed Methods Approach $3^{\text {rd }}$ Edition. USA-California: Thousand Oaks 91320. 2009 (Indonesia Publisher: Pustaka Pelajar, Jakarta)

Creswell, J. 2012. Educational Research: Planning, Conducting and Evaluating Quantitative and Qualitative Research $4^{\text {th }}$ Edition. Upper Saddle River, NJ: Pearson Education.

David, Fred R., .2011. Strategic Management Concepts.

13th ed. New Jersey: Pearson Prentice Hall.

Day, George S; and Nedungadi, Prakash. 1994. Managerial Representation of Competitive Advantage. Journal of Marketing, Volume 58. USA, Chicago: American Marketing
Association

Day, George S.; and Wensley, Robin. 1988. A Framework for Diagnosing Competitive. Journal of Marketing, April 1988, 52,2: Proquest.

Dess, G. G., Lumpkin, G. T., \& Eisner, A. B. (2005). Strategic Management: Creating Competitive Advantages. McGraw-Hill/Irwin.

Drucker, Peter. F. 1985. Innovation and Entrepreneurship: Practice and Principles. Harper and Row.

Eisenhardt, Kathleen M. and Martin, Jeffrey A., 2000. Dynamic Capabilities: What are They?. Strategic Management Journal (WileyBlackwell) 21 (10/11): 1105-1122. Retrieved 2012-05-23.

Firmanzah, 2012. SOE's CEO and Business Transformation. Tempo Magazine, Jakarta, Indonesia.

Lawson, Benn and Samson, Danny, 2001. Developing Innovation Capability in Organizations: $A$ Dynamic Capabilities Approach. International Journal of Innovation Management, Vol. 5, Nr 3 (September 2001) pp. 377-400

Ó hÓbáin, Lorcán, 2012. The Emergence of Dynamic Capabilities in SMEs: A Critical Realist Study. PhD thesis, Dublin City University.

Porter, M.E. and Stern, S., 1999. The New Challenge to America's Prosperity: Findings from the Innovation Index. Washington D.C: Council on Competitiveness, pp. 1-94

Porter, M 1985. Competitive Advantage: Creating And Sustaining Superior Performance, 1st ed, The Free Press, New York, New York, U.S.A.

Priem, R.I and Butler, J.E. 2000. Is the Resource-Based "View" a useful perspective for strategic Management Research? Academy of Management Review 26, Hal. 85-40.

Rodman, David. 2012. General Introduction: Indigenous Knowledge System for Poverty Reduction. Handbook for Lectures and Tutors of the New Master Course on Integrated Microfinance Management for Poverty Reduction and Sustainable Development in Indonesia (IMM).

Scott, Mark C., 2000. Re-inspiring The Corporation. New York: John Willey \& Sons Ltd.

Siagian, Sondang P., 2002. Strategies to Accelerated Work Productivity. Jakarta: Rineka Cipta.

Management for Poverty Reduction and Sustainable Development in Indonesia (IMM).

Soetjitro, Pandu, 2011. (Organizational Transformation using $4 R \quad$ Approach. 
http://jurnal.unimus.ac.id/index.php/vadded/arti c le/view/724.

Teece, David J., 2009. Dynamic Capabilities and Strategic Management. Oxford: Oxford University Press.

Teece, David J., 2008. Technological Know-How: Organizational Capabilities, and Strategic Management: Business Strategy and Enterprise Development in Competitive Environments, 1st edn, World Scientific Publishing Co.Pte. Ltd, Singapore, Singapore.

Teece, David J.; Pisano, Gary and Shuen, Amy, 2007. Dynamic Capabilities and Strategic Management. Strategic Management Journal (Wiley-Blackwell) 18 (7): 509-533.

Teece, D., 2007. Explicating Dynamic Capabilities: The Nature and Microfoundations of Sustainable Enterprise Performance. Strategic Management Journal. 28: 1319-1350.

Teece, D., Pisano, G., and Shuen, A., 1997. Dynamic Capabilities and Strategic Management. Strategic Management Journal. 18: 509-533. 